\title{
Analisis Scientometrics Penelitian Merkuri pada Penambangan Emas Skala Kecil di Indonesia Tahun 2009-2019
}

\author{
Melania Hanny Aryantie ${ }^{1}$, Muhamad Yusup Hidayat ${ }^{2}$, Dewi Ratnaningsih ${ }^{2}$, dan Eva \\ Lindasari Nasution ${ }^{2}$
}

1Puslitbang Kualitas dan Laboratorium Lingkungan KLHK; e-mail: melania.hanny@gmail.com

${ }^{2}$ Puslitbang Kualitas dan Laboratorium Lingkungan KLHK

\begin{abstract}
ABSTRAK
Penelitian ini menggunakan analisis scientometrics untuk mengetahui perkembangan penelitian merkuri pada penambangan emas skala kecil (PESK) di Indonesia tahun 2009-2019. Bidang ilmu scientometrics belum populer di Indonesia. Padahal ilmu ini berguna untuk melakukan evaluasi perkembangan ilmu pengetahuan, evaluasi kinerja riset, dan mendukung efisiensi manajemen riset. Basis data yang dipilih dalam penelitian ini adalah portal Garba Rujukan Digital (GARUDA) milik Kementerian Riset, Teknologi, dan Pendidikan Tinggi (Kemristekdikti) saat itu. Abstrak dari 81 publikasi ilmiah tersortir dianalisis menggunakan content analysis berdasarkan kategori yang diturunkan dari Peraturan Presiden Nomor 21/2019 tentang Rencana Aksi Nasional Pengurangan dan Penghapusan Merkuri (RAN-PPM). Enam kategori terdiri dari: penyimpanan merkuri dan limbah merkuri, pemulihan dan rehabilitasi lahan bekas PESK, pemantauan merkuri, peta sumber merkuri dan peta dampak emisi merkuri, jalur distribusi merkuri dari hulu ke hilir, dan sosial ekonomi. Keenam kategori tersebut mendasari kuantifikasi publikasi, penulis, lembaga afiliasi, dan sitasi. Riset membuktikan bahwa publikasi PESK tertinggi dihasilkan tahun 2015 (14 artikel), publikasi terbanyak adalah pemantauan merkuri (32 artikel), naskah terbanyak dihasilkan oleh peneliti Lembaga Ilmu Pengetahuan Indonesia (LIPI) dan Universitas Sam Ratulangi (UNSRAT) (masing-masing 3 artikel), lembaga afiliasi paling produktif adalah UNSRAT (11 artikel), serta sitasi terbanyak pada tahun 2012 (42 sitasi). Publikasi tentang pemantauan merkuri di PESK diambil sebagai contoh evaluasi perkembangan riset. Data Sungai Talawaan dianalisis untuk media sedimen dan air. Hasilnya ditemukan hubungan yang kuat antara konsentrasi merkuri di media air sesuai pertambahan tahun, sementara di media sedimen tidak signifikan. Temuan yang menjadi rekomendasi adalah kebutuhan riset untuk kegiatan yang minim publikasi, yakni penyimpanan merkuri dan limbah merkuri serta riset tentang alur suplai hingga penggunaan merkuri di PESK. Hasil studi ini menjadi masukan pemerintah tentang pencapaian Indonesia dalam penghapusan merkuri di bidang prioritas PESK serta bahan evaluasi pelaksanaan Konvensi Minamata (Undang-undang Nomor 11/2017) dan pelaksanaan RAN-PPM (Peraturan Presiden Nomor 21/2019).
\end{abstract}

Kata kunci: Indonesia, Merkuri, Minamata, Rakyat, Tambang emas

\begin{abstract}
This study used scientometrics analysis to determine the development of mercury research in small scale gold mining (ASGM) in Indonesia in 2009-2019. Scientometrics is not yet popular in Indonesia. Though it is useful for evaluating science development, research performance, and research management efficiency. The database chosen was Garba Rujukan Digital (GARUDA) belonged to Ministry of Research, Technology and Higher Education. Abstracts from 81 sorted scientific publications were analyzed using content analysis based on categories derived from Presidential Regulation Number 21/2019 concerning the National Action Plan for Mercury Reduction and Elimination. The six categories consist of: mercury and mercury waste storage, recovery and rehabilitation of former ASGM sites, mercury monitoring, mercury source maps and mercury emission impact maps, mercury distribution channels, and socioeconomic. The six categories underlie the quantification of publications, authors, affiliations, and citations. Research showing the most publications were produced in 2015 (14 articles), the most category was mercury monitoring (32 articles), the most manuscripts were produced by the Indonesian Institute of Sciences and Sam Ratulangi University (UNSRAT) ( 3 articles each), the most productive affiliation was UNSRAT (11 articles), and the most citations were in 2012 (42 citations). Publications on mercury monitoring were taken as an example of evaluation. Talawaan River data were analyzed for sediment and water media. The results were significant between mercury concentrations in water over the years, while sediment were not. The recommendation is for the research with minimal publicity activities, namely the storage of mercury and mercury waste along with research on the supply channel to the use of mercury in ASGM. The results of this study are the government's input on Indonesia's achievement in the elimination of mercury in the ASGM priority areas as well as evaluation materials for the implementation of the Minamata Convention and the implementation of the national action plan.
\end{abstract}

Keywords: Artisanal, Gold mining, Indonesia, Mercury, Minamata

Citation: Aryantie, M.H., Hidayat, M.Y., Ratnaningsih, D., dan Nasution, E.L. (2020). Analisis Scientometrics Penelitian Merkuri pada Penambangan Emas Skala Kecil di Indonesia Tahun 2009-2019. Jurnal Ilmu Lingkungan, 18(1), 185-192, doi:10.14710/jil.18.1.185-192 


\section{Pendahuluan}

Pencemaran merkuri telah menjadi masalah yang menjadi perhatian secara internasional. Dampak pencemaran merkuri yang nyata secara fisik dan menimbulkan kerugian bagi kesehatan manusia dan mahkluk hidup telah dibuktikan dengan kasus penyakit di Teluk Minamata, Jepang. Tragedi Teluk Minamata merupakan bencana pencemaran merkuri terbesar hingga ditetapkan sebagai sebuah konvensi internasional pada tahun 2013. Indonesia, sebagai salah satu negara yang meratifikasi konvensi tersebut, terikat beberapa kewajiban untuk melakukan upaya penghapusan merkuri (UU Nomor 11/2017 tentang Pengesahan Minamata Convention On Mercury (Konvensi Minamata Mengenai Merkuri)). Bukti implementasi sebagai negara peserta konvensi, Indonesia telah menghasilkan Rencana Aksi Nasional Pengurangan dan Penghapusan Merkuri (RAN-PPM) yang ditetapkan melalui Peraturan Presiden (Perpres) No. 21/2019. Upaya pengurangan dan penghapusan merkuri tidak cukup sampai penerbitan peraturan tersebut, Indonesia perlu melaksanakan kesepakatan dalam matriks RAN-PPM hingga tahun 2030.

Untuk isu lingkungan dikaitkan dengan tugas pokok dan fungsi lembaga pemerintah, maka instansi yang bertanggung jawab saat ini adalah Kementerian Lingkungan Hidup dan Kehutanan (KLHK). Dalam keempat bidang prioritas yang ditetapkan (manufaktur, energi, pertambangan emas skala kecil/PESK, dan kesehatan), KLHK menjadi instansi penanggung jawab untuk beberapa strategi.

Dalam implementasi RAN-PPM terkait dengan penelitian dan pemantauan merkuri, maka telah dibentuk Komite Penelitian dan Pemantauan Merkuri (KPPM) melalui Keputusan Menteri Lingkungan Hidup dan Kehutanan RI Nomor: SK.340/Menlhk/Setjen/Kum.1/8/2018 tentang Komite Penelitian dan Pemantauan Merkuri di Indonesia. Tugas dari KPPM ini diantaranya adalah untuk mengumpulkan informasi hasil kegiatan penelitian dan pemantauan merkuri serta melakukan evaluasi terhadap kegiatan penelitian dan pemantauan merkuri. Dalam mendukung tugas KPPM tersebut diperlukan informasi terkait dengan penelitian dan pemantauan merkuri yang telah dilakukan di Indonesia termasuk kegiatan merkuri yang berkaitan dengan pertambangan emas skala kecil (PESK). Informasi hasil pemantauan dan penelitian tersebut perlu dievaluasi sebagai saran kebijakan kepada para pemangku kepentingan. Data mengenai penelitian merkuri dapat diperoleh melalui analisis scientometrics (Pinto, Dórea, Bernardi, \& Gomes, 2019), cabang ilmu yang memiliki kelebihan penyelidikan untuk bidang ilmiah (Leydesdorff, 2001). Meskipun ada sanggahan dari Kenna, Mryglod, \& Berche (2017) bahwa tidak semua hal dapat dihitung menggunakan scientometrics, akan tetapi analisis ini dapat dimanfaatkan untuk mencapai tujuan penelitian. Tujuan riset ini adalah untuk mengetahui perkembangan penelitian terkait merkuri pada PESK di Indonesia, sehingga hasil studi ini dapat digunakan untuk mendukung penerapan RAN-PPM dan pelaksanaan Konvensi Minamata berdasarkan hukum yang berlaku.

Riset merkuri termasuk dalam bidang prioritas PESK. Metode yang digunakan adalah analisis scientometrics sebagai salah satu cabang dari ilmu sosiologi dan publikasi untuk mengukur perkembangan sebuah ilmu. Pelaku scientometrics perlu memetakan pemrosesan informasi yang sistematis dari ilmu yang diteliti (Leydesdorff, 2001). Hasil studi menggambarkan status penelitian dari beberapa disiplin ilmu (Wang, Xue, Zhang, \& Luo, 2018). Metode ini dipakai untuk mengetahui perkembangan penelitian (Lukman, Hidayat, AlHakim, \& Nadhiroh, 2019) tentang merkuri di PESK di Indonesia selama tahun 2009-2019. Berpedoman pada Perpres No. 21/2019, seluruh PESK ditargetkan untuk dihapus pada tahun 2025. Oleh karena itu, hasil riset ini dapat menjadi rekomendasi untuk menindaklanjuti strategi RAN-PPM yang belum dilaksanakan.

\section{Metode Penelitian}

Penelitian dilakukan pada bulan Maret-Juli 2019. Pada periode tersebut, publikasi tahun 2019 sudah terbit selama satu semester. Batas waktu pengumpulan data ditentukan dengan pertimbangan jumlah publikasi yang terus bertambah dan waktu penyelesaian penelitian ini adalah satu tahun. Basis data yang dipilih dalam penelitian ini adalah portal Garba Rujukan Digital (GARUDA) milik Kementerian Riset, Teknologi, dan Pendidikan Tinggi (Kemristekdikti) sebelum berganti nomenklatur menjadi Kementerian Riset dan Teknologi/Badan Riset dan Inovasi Nasional (Kemristek/BRIN). Alasan yang mendasari pemilihan GARUDA adalah sebagai portal jurnal milik pemerintah Indonesia, memiliki sistem akses terbuka, dan lokus riset dominan di Indonesia sesuai dengan fungsi KPPM. Selain GARUDA, penelitian juga memanfaatkan data hasil pemantauan merkuri milik Pusat Sarana Pengendalian Dampak Lingkungan (PUSARPEDAL) Kementerian Lingkungan Hidup (KLH) tahun 20062008. Data ini digunakan untuk mengetahui perkembangan pemantauan lingkungan di lokasi PESK yang beririsan dengan data scientometrics yang diperoleh. Tantangan memanfaatkan portal GARUDA sebagai sumber data adalah tidak dapat terdeteksi oleh beberapa perangkat lunak pemetaan scientometrics yang populer (VOSviewer, HistCite, dan CiteSpace) sehingga pengolahan data dilakukan secara manual.

Langkah-langkah yang dilakukan adalah 1) mengakses data GARUDA melalui pilihan advanced 
search: search by "abstract", source title "mercury", dan filter by year "2009-2019", 2) artikel yang dipilih dalam bahasa Indonesia dan Inggris, 3) batas waktu mengakses data hingga tanggal 7 Juli 2019. Batasan waktu pengaksesan diterapkan untuk menghindari data yang semakin berkembang. Rentang tahun terbit artikel selama 11 tahun ditetapkan dengan alasan Konvensi Minamata dimulai tahun 2010 dan berlaku tahun 2013 (Badan Pembinaan Hukum Nasional, 2017) serta syarat minimal data berkelanjutan selama 10 tahun untuk dinyatakan kuat secara statistik (White, 2019). Ini berbeda dengan yang dilakukan Pinto, Dórea, Bernardi, \& Gomes (2019) dan Wang et al. (2018) yang menentukan awal penelitian berdasarkan tahun diterbitkannya artikel pertama dengan topik yang diteliti.

Topik penelitian merkuri di Indonesia sangat luas. Oleh karena itu peneliti membatasi ruang lingkup berdasarkan rencana strategis RAN-PPM, tugas dan fungsi KPPM, dan kegiatan PESK (teknik pengambilan data purposive sampling.) Kategorisasi topik bidang prioritas PESK khusus wewenang KLHK diekstrak dari Perpes No. 21/2019 tentang RAN-PPM. Dari 19 kegiatan utama, dilakukan pengelompokan dan kodifikasi menjadi 6 (enam) topik besar (Tabel 1). Untuk mengetahui topik dan ruang lingkup utama dari naskah publikasi yang diteliti, kami memilih membaca dan menganalisa abstrak. Bukan hanya judul naskah dan kata kunci. Metode penelitian adalah kualitatif deskriptif.

Metode analisis scientometrics paling tidak mencakup evaluasi kecenderungan peningkatan publikasi tiap tahun (regresi) serta koneksi jejaring antara majalah ilmiah, penulis, lembaga penulis, sitasi, negara, kata kunci, co-authors, dan lain-lain (Pinto et al., 2019). Analisis scientomentrics berfokus pada distribusi penulis utama dan lembaga-lembaganya, kategori dan kata kunci frekuensi tinggi, jurnal berpengaruh tinggi, kontribusi penulis, dan tren evolusioner berdasarkan analisis penulis bersama, analisis bersama, analisis koitasi dan analisis kumpulan dokumen (Wang et al., 2018). Untuk analisis yang dilakukan dalam riset ini sedikit berbeda meliputi data terkait topik PESK yang telah dikategorikan, nama penulis dan jumlah publikasi yang dihasilkan, tahun terbit, afiliasi lembaga penulis, dan jumlah sitasi publikasi. Keterbatasan dari riset ini meliputi: 1) penapisan dan analisis dilakukan secara manual dan berdasarkan persepsi masing-masing kontributor penelitian, 2) portal target GARUDA tidak terdeteksi beberapa perangkat lunak scientometrics populer, dan 3) rentang waktu publikasi dibatasi untuk 11 tahun terakhir.

\section{Hasil dan Pembahasan \\ 3.1. Analisis Scientometrics}

Scientometrics digunakan untuk mengukur tingkat perkembangan ilmu pengetahuan dan manfaatnya bagi manusia (Sengupta, 1992; Lukman et al., 2019) pada rentang waktu yang ditentukan oleh peneliti. Scientometrics bertujuan untuk menguantifikasi ilmu pengetahuan pada tingkat individu, lembaga, lingkup nasional/ internasional, dan berbagai cabang ilmu (Sengupta, 1992). Dari teori Sengupta, kami memilih kuantifikasi tingkat individu, lembaga dan lingkup nasional. Cabang ilmu diwakili oleh pengelompokan topik riset merkuri pada PESK.

Tujuan riset adalah untuk mengetahui perkembangan penelitian terkait merkuri pada PESK di Indonesia. Sasarannya adalah mendukung penerapan RAN-PPM dan pelaksanaan Konvensi Minamata berdasarkan hukum yang berlaku. Gambar 1 adalah pemetaan legislasi terkait merkuri untuk menguraikan dasar kategori data penelitian.

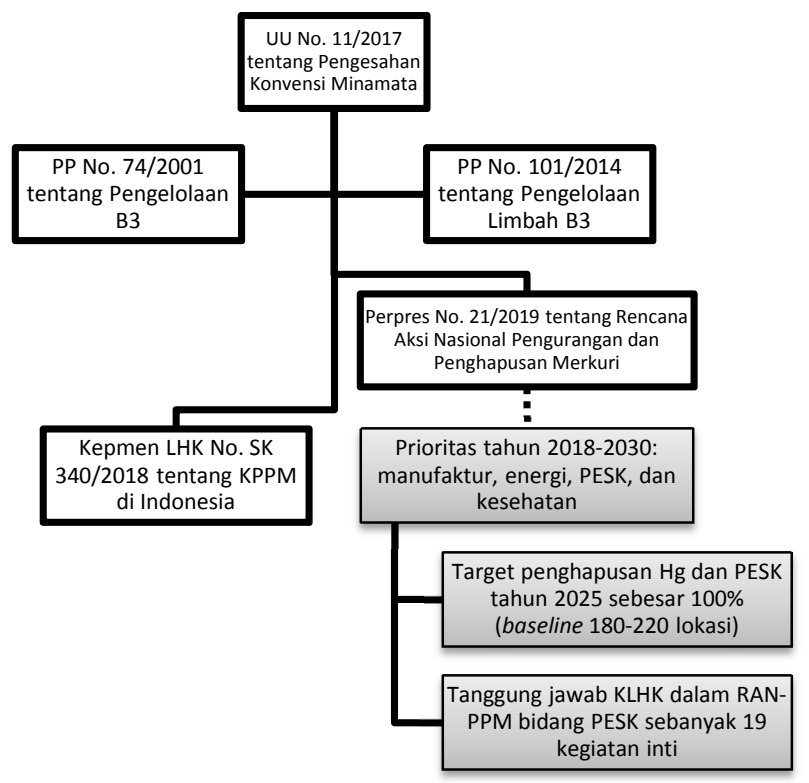

Gambar 1 Alur tugas KLHK terkait merkuri pada PESK dari sisi peraturan perundangan. 
Sembilan belas kegiatan penghapusan merkuri yang menjadi tanggung jawab KLHK, tercantum dalam Lampiran II RAN-PPM, kemudian dikelompokkan menjadi 6 kategori/gugus topik. Keenam gugus tersebut disampaikan pada Tabel 1. Terdapat empat kegiatan yang tidak dapat dikategorikan* ke dalam gugus karena di luar ruang lingkup penelitian dan pemantauan merkuri (c.2.2.1. kerjasama antar stakeholders, c.6.3.2. pembangunan fasilitas pengolahan emas tanpa merkuri, dan c.6.4.2. penyediaan fasilitas penyimpanan merkuri) serta definisi umum yang sudah diakomodir dalam 6 kategori topik (c.3.1.2. riset merkuri).

Tabel 1. Gugus topik rencana strategis terkait RAN-PPM (Lampiran II Perpres No. 21/2019).

\begin{tabular}{|c|c|c|c|c|}
\hline \multicolumn{4}{|c|}{ Uraian kegiatan bidang prioritas PESK } & \multirow{2}{*}{$\begin{array}{l}\text { Gugus (clustering) } \\
\text { Gugus 1: penyimpanan } \\
\text { merkuri dan limbah } \\
\text { merkuri }\end{array}$} \\
\hline $\begin{array}{l}\text { c.1.1.4. penyimpanan dan } \\
\text { penanganan merkuri dan } \\
\text { limbah merkuri }\end{array}$ & $\begin{array}{l}\text { c.6.4.1. FS dan DED fasilitas } \\
\text { penyimpanan merkuri }\end{array}$ & & & \\
\hline $\begin{array}{l}\text { c.1.1.5. pemulihan lahan } \\
\text { terkontaminasi merkuri }\end{array}$ & $\begin{array}{l}\text { c.5.1.7. pedoman } \\
\text { pemulihan lahan } \\
\text { terkontaminasi merkuri }\end{array}$ & $\begin{array}{l}\text { c.6.2.1. pemulihan lahan } \\
\text { terkontaminasi merkuri } \\
\text { dan rehabilitasi lahan } \\
\text { bekas tambang emas }\end{array}$ & & $\begin{array}{l}\text { Gugus 2: pemulihan } \\
\text { dan rehabilitasi lahan } \\
\text { bekas PESK }\end{array}$ \\
\hline $\begin{array}{l}\text { c.2.3.1. pemantauan } \\
\text { kualitas lingkungan }\end{array}$ & $\begin{array}{l}\text { c.3.1.1. laboratorium } \\
\text { lingkungan dan } \\
\text { pemantauan merkuri }\end{array}$ & & & $\begin{array}{l}\text { Gugus 3: pemantauan } \\
\text { merkuri }\end{array}$ \\
\hline $\begin{array}{l}\text { c.4.1.1. peta dampak } \\
\text { emisi dan lepasan } \\
\text { merkuri terhadap } \\
\text { lingkungan }\end{array}$ & $\begin{array}{l}\text { c.4.1.5. peta sebaran batu } \\
\text { sinabar dan merkuri }\end{array}$ & & & $\begin{array}{l}\text { Gugus 4: peta sumber } \\
\text { merkuri dan peta } \\
\text { dampak emisi merkuri }\end{array}$ \\
\hline $\begin{array}{l}\text { c.4.1.4. database } \\
\text { perdagangan, peredaran, } \\
\text { dan penggunaan merkuri }\end{array}$ & $\begin{array}{l}\text { c.4.1.6. inventarisasi dan } \\
\text { peta sumber, suplai } \\
\text { pengadaan, peredaran, dan } \\
\text { penggunaan merkuri }\end{array}$ & & & $\begin{array}{l}\text { Gugus 5: jalur } \\
\text { distribusi merkuri dari } \\
\text { hulu ke hilir }\end{array}$ \\
\hline $\begin{array}{l}\text { c.5.1.2. kampanye risiko } \\
\text { dampak penggunaan } \\
\text { merkuri dan isu gender }\end{array}$ & $\begin{array}{l}\text { c.7.1.1. kajian sosial } \\
\text { dampak penggunaan } \\
\text { merkuri di PESK }\end{array}$ & $\begin{array}{l}\text { c.7.1.2. kajian ekonomi } \\
\text { dampak penggunaan } \\
\text { merkuri }\end{array}$ & $\begin{array}{l}\text { c.7.2.1. } \\
\text { transformasi sosial } \\
\text { ekonomi } \\
\text { penambang ilegal }\end{array}$ & $\begin{array}{l}\text { Gugus 6: sosial dan } \\
\text { ekonomi }\end{array}$ \\
\hline $\begin{array}{l}\text { c.2.2.1. kerjasama } \\
\text { pengurangan dan } \\
\text { penghapusan merkuri } \\
\text { dengan stakeholders }\end{array}$ & c.3.1.2. riset merkuri & $\begin{array}{l}\text { c.6.3.2. pembangunan } \\
\text { fasilitas pengolahan emas } \\
\text { tanpa merkuri }\end{array}$ & $\begin{array}{l}\text { c.6.4.2. penyediaan } \\
\text { fasilitas } \\
\text { penyimpanan } \\
\text { merkuri }\end{array}$ & Tidak dikelompokkan* \\
\hline
\end{tabular}

Sumber data diolah dari RAN-PPM 2019

Ruang lingkup penelitian ditentukan mencakup bagian naskah yang disasar, kata kunci, dan waktu pengunduhan naskah (Sengupta, 1992; Pinto et al., 2019). Kami menentukan bagian naskah yang disasar adalah intisari (abstract), bukan bagian judul seperti yang Pinto et al. (2019) lakukan karena abstrak menggambarkan pokok tulisan dan menjelaskan keterkaitan penelitian dengan PESK. Sementara itu, kata kunci yang dipilih adalah mercury karena menghasilkan jumlah naskah terbanyak yang bisa diakses pada portal GARUDA daripada menggunakan istilah merkuri, raksa, air raksa, hydrargyrum, atau quicksilver.

Dari batasan yang ditetapkan, maka dilakukan langkah-langkah: 1) search by: abstract, 2) year: 20092019, dan 3) keywords: mercury. Jumlah artikel total yang diakses dari situs GARUDA Kemristekdikti sebanyak 494 naskah per tanggal 7 Juli 2019. Kemudian seluruh naskah tersebut disortir untuk bidang prioritas PESK dan ditapis berdasarkan kategori/gugus 6 topik pada Tabel 1. Dari hasil penapisan bidang PESK, maka diperoleh naskah sebanyak 81 buah (Gambar 2). Dari grafik tersebut terlihat bahwa tahun 2015 merupakan tahun saat para penulis paling produktif menghasilkan publikasi terkait merkuri pada PESK. Tiga tahun berikutnya riset merkuri di PESK cenderung menurun. Tahun
2019 belum dapat disimpulkan karena baru berjalan satu semester saat penelitian dilakukan.

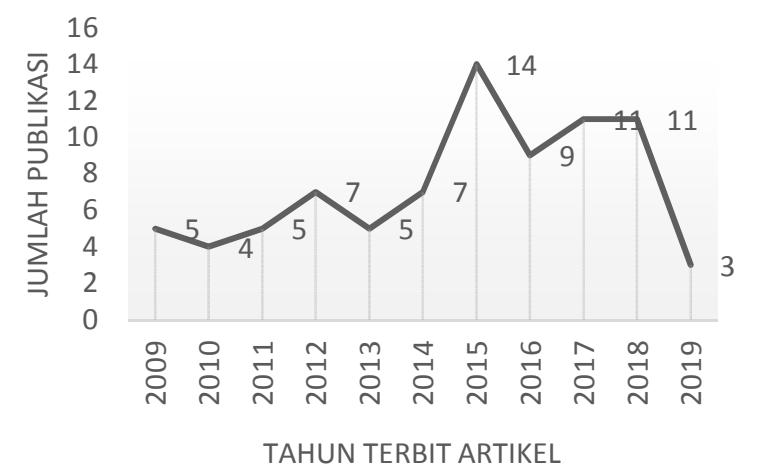

Gambar 2 Jumlah publikasi ilmiah di Indonesia dengan topik PESK tahun 2009-2019

Jumlah publikasi didetilkan lagi per gugus topik/kategori (cluster). Perkembangan jumlah publikasi per kategori mengacu pada Hardiyati et al. (2018). Fungsinya untuk penyusunan rencana penempatan anggaran penelitian untuk kategori yang minim riset. Dengan kata lain untuk mendorong manajemen riset yang tepat guna (Lukman et al., 2019). Pada Gambar 3 terlihat bahwa publikasi didominasi oleh topik pemantauan merkuri pada PESK di tahun 2015. Urutan berikutnya adalah penelitian dengan gugus sosial ekonomi tahun 20162017 dan gugus pemulihan tahun 2018. Sementara 
itu, publikasi yang masih minim terkait topik penyimpanan merkuri dan limbahnya serta topik distribusi merkuri dari hulu (penyedia) ke hilir (penambang). Minimnya publikasi karena topik tersebut berhubungan dengan rantai perdagangan merkuri ilegal/pelanggaran hukum (Nimitch, 2012). Nimitch (2012) menyatakan bahwa perusahaan pengimpor merkuri resmi yang ditunjuk pemerintah tidak pernah menjual merkuri kepada para penambang di wilayah studi. Kedua gugus topik ini menjadi masukan untuk didorong supaya lebih maju dan berkembang, khususnya untuk mendukung penghapusan merkuri pada PESK Indonesia tahun 2025.

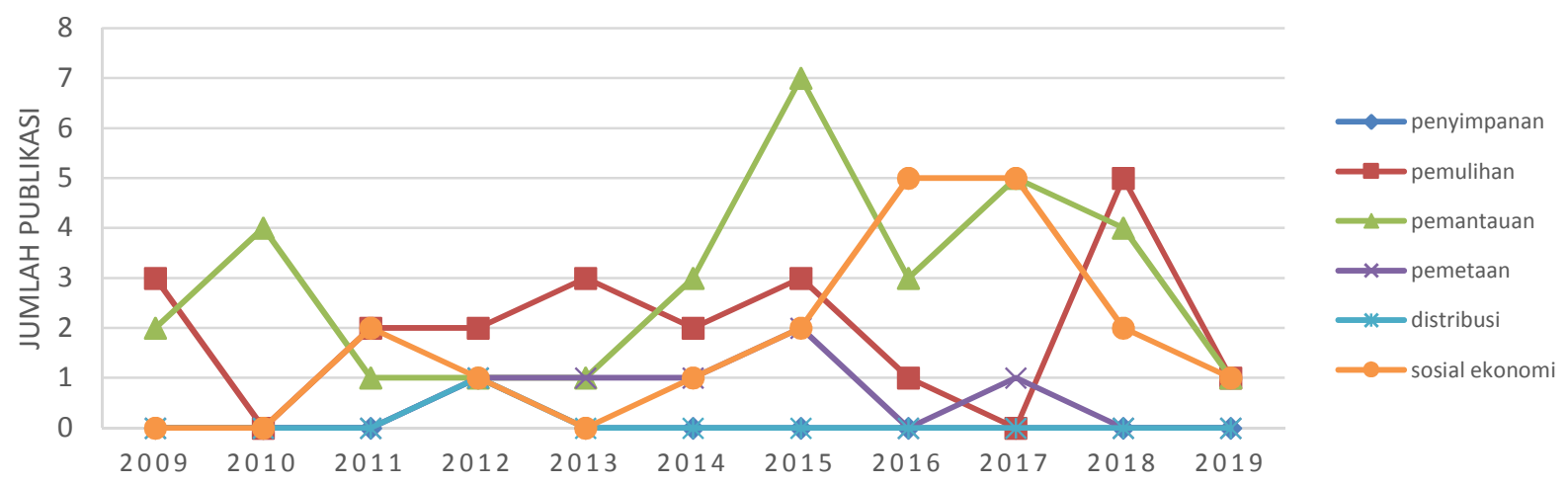

Gambar 3 Distribusi topik publikasi ilmiah merkuri pada PESK di Indonesia tahun 2009-2019.

Saat pengumpulan data, kami menyarikan abstrak dan mengelompokkan topik artikel sesuai dengan penggugusan pada Tabel 1. Hasil yang diperoleh (Gambar 4) memperlihatkan bahwa artikel dengan topik pemantauan merkuri (gugus 3) mendominasi publikasi, diikuti oleh topik mengenai pemulihan dan rehabilitasi lahan bekas PESK (gugus 2), sosial dan ekonomi (gugus 6), peta sumber merkuri dan peta dampak emisi merkuri (gugus 4), penyimpanan merkuri dan limbah merkuri (gugus 1) dan jalur distribusi merkuri dari hulu ke hilir (gugus 5). Dari hasil ini, pihak pengambil kebijakan dan pengguna data dapat memanfaatkannya sebagai data capaian Indonesia dalam memenuhi penerapan RANPPM untuk kegiatan-kegiatan yang terkait gugus tertentu. Meskipun masih terjadi perdebatan pemanfaatan scientometrics untuk masukan kebijakan nasional (Kenna et al., 2017), namun dari analisis terhadap penelitian merkuri pada PESK di Indonesia ini dapat diambil tindakan. KPPM sebagai stakeholder utama evaluator kegiatan litbang merkuri perlu mendorong penelitian-penelitian yang masih kurang yakni penyimpanan merkuri dan limbah merkuri serta jalur distribusi (perdagangan, peredaran, dan penggunaan) merkuri di Indonesia.

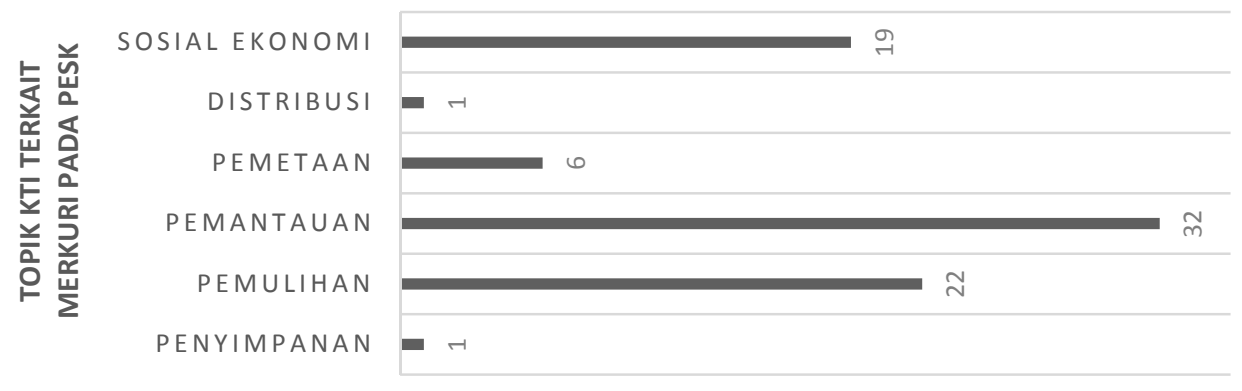

JUMLAH PUBLIKASI

Gambar 4 Jumlah publikasi ilmiah dikaitkan dengan rencana strategis penghapusan merkuri (Perpres No. 21/2019).

Dari hasil penelitian terkumpul nama 214 orang penulis artikel bertopik merkuri pada PESK yang menghasilkan publikasi sejumlah 1 hingga 3 naskah dalam rentang waktu 11 tahun. Penulis dengan satu buah naskah sebanyak 93\% (199 orang), penulis dengan dua buah artikel sebanyak 6\% (13 orang), dan penulis dengan tiga buah naskah sebanyak $1 \%$ (2 orang) (Gambar 5). Penulis dengan naskah terbanyak adalah Nuril Hidayati dari Pusat Penelitian Biologi LIPI dan Jemmy Abidjulu dari Fakultas MIPA Universitas Sam Ratulangi, Manado.

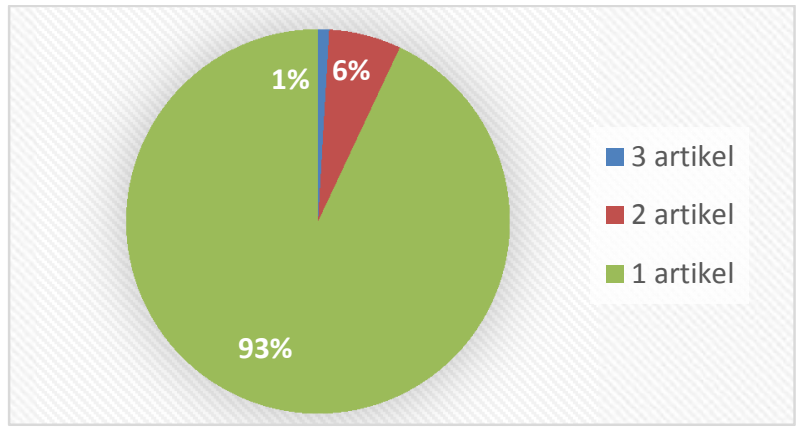

Gambar 5 Persentase penulis dengan jumlah publikasi ilmiah yang dihasilkan tahun 2009-2019. 
Hasil analisis scientometrics yang terakhir adalah afiliasi tempat penulis menjalankan penelitiannya. Jumlah lembaga yang tercatat selama penelitian ini sebanyak 52 afiliasi terdiri dari lembaga pemerintah, pemerintah daerah, dan perguruan tinggi. Dari Gambar 6 terlihat bahwa Universitas Sam Ratulangi (UNSRAT) adalah lembaga yang memiliki penulis paling produktif (11 artikel), diikuti oleh Kementerian Energi dan Sumberdaya Mineral (KESDM) serta Lembaga Ilmu Pengetahuan Indonesia (LIPI) masingmasing 6 (enam) artikel. Afiliasi dengan 5 (lima) naskah adalah Universitas Gadjah Mada (UGM), Universitas Tanjungpura (UNTAN), Universitas Brawijaya (UB), dan Universitas Tadulako (UNTAD). Afiliasi dengan 4 (empat) naskah adalah Universitas Syiah Kuala (UNSYIAH) dan Universitas Diponegoro (UNDIP). Afiliasi dengan 3 (tiga) naskah adalah Universitas Padjajaran (UNPAD), Institut Pertanian Bogor (IPB), dan Universitas Indonesia (UI). Terakhir, afiliasi yang menghasilkan 2 (dua) naskah dalam 11 tahun terakhir adalah Kementerian Pertanian (KEMENTAN), Universitas Sebelas Maret (UNS), Kementerian Kesehatan (KEMENKES), Universitas Riau (UR), Universitas Lambung Mangkurat (UNLAM), Universitas Pattimura (UNPATTI), Kementerian Lingkungan Hidup dan Kehutanan (KLHK), Universitas Palangka Raya (UPR), dan Universitas Teuku Umar (UTU). Sementara itu, 31 afiliasi lainnya menghasilkan 1 (satu) naskah publikasi.

Sebagai catatan, penulisan afiliasi digeneralisir menjadi unit lembaga tertinggi yang menaungi unit kerja yang melaksanakan riset. Contohnya adalah LIPI yang terdiri dari Pusat Penelitian Biologi, Pusat Penelitian Geoteknologi, dan Kebun Raya Bogor. Contoh dari perguruan tinggi adalah UNDIP yang terdiri dari Fakultas Kesehatan Masyarakat, Fakultas Perikanan dan Ilmu Kelautan, Fakultas Kedokteran, dan Magister Kesehatan Lingkungan.

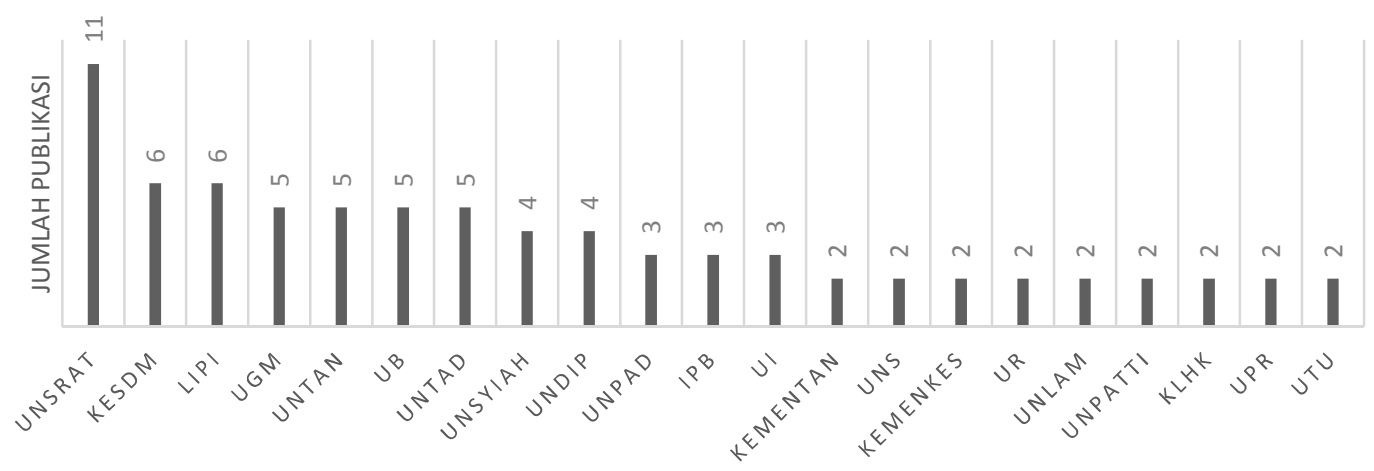

LEMBAGA AFILIASI PENULIS KTI

Gambar 6 Produktivitas lembaga afiliasi dengan publikasi ilmiah terkait merkuri di PESK.

Dampak publikasi dapat dilihat dari banyaknya sitasi terhadap artikel ilmiah yang terbit (Silalahi, Santoso, \& Hidayat, 2019). Dengan sitasi, maka sebuah penelitian dapat dikatakan berdampak terhadap pihak lain dan bermanfaat. Dari Gambar 7 terlihat bahwa jumlah sitasi terbanyak ditemukan pada publikasi di tahun 2012 (42 sitasi), diikuti tahun 2010 (21 sitasi) dan
2011 (17 sitasi). Jika dibandingkan dengan Gambar 2 yang menunjukkan jumlah publikasi meningkat mulai tahun 2015 tetapi sitasinya lebih sedikit, maka ada dua kemungkinan. Pertama, keterbatasan jumlah referensi yang diacu pada periode 2010-2012. Kedua, publikasi yang berdampak secara keilmuan sulit ditemukan setelah periode tersebut.

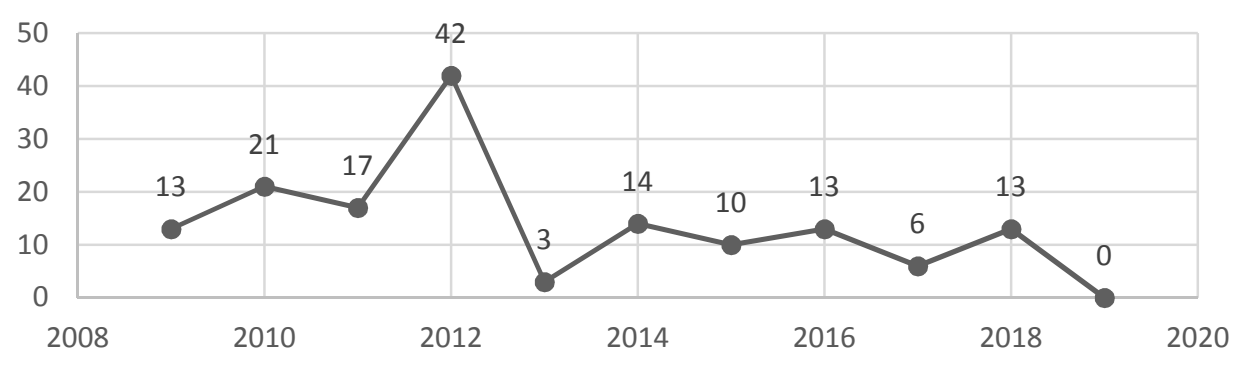

Gambar 7 Jumlah sitasi publikasi ilmiah terkait merkuri pada PESK tahun 2009-2019.

\subsection{Pemantauan Merkuri di Lokasi PESK}

Artikel ilmiah pemantauan merkuri menjadi hasil analisis scientometrics dengan jumlah publikasi terbanyak selama 11 tahun terakhir. Pemantauan merkuri merupakan salah satu amanat peraturan perundang-undangan yang berlaku (UU Nomor 11/2017; SK.340/Menlhk/Setjen/Kum.1/8/2018). Data pemantauan lingkungan penting untuk mendeteksi perubahan kualitas lingkungan (Esterby, 1993). Publikasi terkait kategori ini diambil sebagai contoh evaluasi perkembangan riset pemantauan merkuri di Indonesia (Lukman et al., 2019).

Dari data publikasi yang dianalisis disandingkan dengan seluruh data pemantauan merkuri di PESK oleh PUSARPEDAL tahun 2006-2008, maka diperoleh satu lokasi pemantauan yang sama. Lokasi dimaksud 
adalah Sungai Talawaan (Sultan, Abidjulu, \& Koleangan, 2015; Komalig, Lasut, \& Tangkuman, 2010). Hasil pemantauan merkuri dilakukan di Sungai Talawaan, Sulawesi Utara pada dua matrik (air dan sedimen) dan diolah dengan hasil analisis statistik sidik ragam (analysis of variance) serta korelasi Pearson.

Data PUSARPEDAL (2006-2008) disandingkan dengan data Komalig et al. (2010) untuk merkuri di sedimen Sungai Talawaan, Minahasa Utara pada Tabel 2. Untuk konsentrasi merkuri di sedimen Sulawesi Utara nilainya tidak berbeda secara signifikan antara tahun 2006-2008 (P>0.01). Tidak terdapat hubungan antara konsentrasi merkuri dengan pertambahan tahun pada tahun 2006-2008. Pada tahun 2010 terlihat bahwa ada penurunan nilai konsentrasi merkuri di sedimen pada seluruh desa dari nilai konsentrasi tahun 2008.

Tabel 2. Konsentrasi merkuri di sedimen Sungai Talawaan.

\begin{tabular}{lcccc}
\hline \multicolumn{1}{c}{ Desa } & $\mathbf{2 0 0 6}$ & $\mathbf{2 0 0 7}$ & $\mathbf{2 0 0 8}$ & $\mathbf{2 0 1 0}$ \\
Wasian & $------(\mathbf{m g} / \mathbf{k g})$ & $-\mathbf{- - - -}$ & $(\mathbf{p p m})$ \\
\hline Tatelu & 0,564 & 3,746 & 3,800 & 0,971 \\
Talawaan & - & 4,846 & 1,500 & 0,608 \\
Talawaan Bantik & - & 7,507 & 5,900 & 1,136 \\
Talawaan Bajo & 0,099 & 0,359 & 0,900 & 0,116 \\
\hline
\end{tabular}

Keterangan: "-“ artinya tidak dilakukan pengambilan data

Sumber: PUSARPEDAL (2006-2008); Komalig et al. (2010)

Data pemantauan kualitas merkuri di air PUSARPEDAL (2006-2008) disandingkan dengan data Sultan et al. (2015) pada Tabel 3. Konsentrasi merkuri di air Sungai Talawaan, Minahasa Utara nilainya berbeda secara signifikan antara tahun 2006$2008(\mathrm{P}<0.01)$. Terdapat hubungan yang kuat antara konsentrasi merkuri dengan pertambahan tahun mulai pada tahun 2006-2008. Terjadi penurunan konsentrasi pada tahun 2006-2008 ( $<<0.01)$. Data 2015 tidak dapat dibandingkan karena limit deteksi alat yang digunakan tidak dapat membaca angka $<0,0007$ ppm.

Tabel 3. Konsentrasi merkuri di air Sungai Talawaan.

\begin{tabular}{lcccc}
\hline \multicolumn{1}{c}{ Desa } & $\mathbf{2 0 0 6}$ & $\mathbf{2 0 0 7}$ & $\mathbf{2 0 0 8}$ & $\mathbf{2 0 1 5}$ \\
& ------- & $(\mathbf{m g} / \mathbf{L})$ & $-\cdots----$ & (ppm) \\
\hline Wasian & 0,3800 & 0,0003 & 0,0003 & $<0,0007$ \\
Talawaan & - & 0,0004 & 0,0003 & $<0,0007$ \\
Talawaan & 0,5700 & 0,0004 & 0,0004 & $<0,0007$ \\
Bajo/muara & & & & \\
\hline
\end{tabular}

Keterangan: "_" artinya tidak dilakukan pengambilan data

Sumber: PUSARPEDAL (2006-2008); Sultan et al. (2015)

Dari analisis publikasi yang dilakukan, diketahui perubahan kualitas lingkungan DAS Sungai Talawaan. Pada data tahun terakhir terlihat bahwa konsentrasi merkuri di sedimen dan air menurun daripada data pemantauan sebelumnya. Menurut Sultan et al., (2015) penyebab menurunnya konsentrasi merkuri adalah penggunaan sianida dalam proses pengolahan emas, sementara merkuri dalam jumlah terbatas masih digunakan dalam teknik amalgamasi. Informasi ini sebagai masukan bagi riset selanjutnya atau bahan pertimbangan pemerintah dalam pengalihan penggunaan merkuri ke bahan/metode lainnya pada PESK.

\section{Kesimpulan}

Dari data yang telah diperoleh, maka data penelitian merkuri pada PESK di Indonesia yang diperoleh meliputi penelitian dengan kategori topik penyimpanan merkuri dan limbah merkuri, pemulihan dan rehabilitasi lahan bekas PESK, pemantauan merkuri, peta sumber merkuri dan peta dampak emisi merkuri, jalur distribusi merkuri dari hulu ke hilir, serta sosial dan ekonomi. Keenamnya mencakup kewenangan KPPM, yakni penelitian dan pemantauan merkuri.

Hasil analisis scientometrics untuk lingkup riset ini menunjukkan bahwa perkembangan penelitian merkuri pada PESK di Indonesia didominasi oleh topik pemantauan merkuri. Sementara itu, riset yang perlu didukung untuk mencapai target RAN-PPM adalah penyimpanan merkuri dan limbah merkuri serta penelitian mengenai jalur distribusi merkuri dari hulu (penyedia) ke hilir (penambang). Dari hasil ini, paling tidak KLHK dapat menyampaikan pencapaian Indonesia dalam penghapusan merkuri di bidang prioritas PESK menurut UU No. 11/2017 dan Perpres No. 21/2019 sampai dengan tahun 2019. Melalui riset ini dinyatakan bahwa analisis scientometrics dapat dimanfaatkan sebagai salah satu alat untuk memberi masukan terhadap kebijakan nasional.

\section{DAFTAR PUSTAKA}

Badan Pembinaan Hukum Nasional. (2017). Hasil Penyelarasan Naskah Akademik Rancangan Undangundang Pengesahan Minamata Convention on Mercury (Konvensi Minamata Mengenai Merkuri). Jakarta. Retrieved from https://www.bphn.go.id/data/documents/na_ruu_ri -minamata.pdf

Esterby, S. R. (1993). Trend Analysis Methods for Environmental Data. Environmetrics, 4(4), 459-481. https://doi.org/10.1002/env.3170040407

Hardiyati, R., Nadhiroh, I. M., Handayani, T., Silalahi, V. M. M., Rahmaida, R., \& Amelia, M. (2018). A Contextual Scientometric Analysis of Indonesian Biomedicine Mapping th Potential of Basic Research Downstreaming. STI Policy and Management Journal, $3(2)$, 67-80. https://doi.org/10.14203/STIPM.2017.134

Kenna, R., Mryglod, O., \& Berche, B. (2017). A scientists' view of scientometrics: Not everything that counts can be counted. Condensed Matter Physics, 20(1), 1-10. https://doi.org/10.5488/CMP.20.13803

Komalig, R., Lasut, M. T., \& Tangkuman, H. D. (2010). Kontaminasi Merkuri Dalam Sedimen di Sungai Talawaan. Chemistry Progress, 3(2), 81-84. Retrieved from

https://ejournal.unsrat.ac.id/index.php/chemprog/a rticle/view/18984/18542

Leydesdorff, L. (2001). The challenge of scientometrics: The development, measurement, and self-organization of scientific communications (2nd ed.). Universal Publishers. Retrieved from http://www.upublish.com/books/leydesdorffsci.htm

Lukman, Hidayat, D. S., Al-Hakim, S., \& Nadhiroh, I. M. (2019). Pengukuran Kinerja Riset: Teori dan 
Implementasi. (Y. Rianto, Ed.). Jakarta: LIPI Press.

Nimitch, M. (2012). Penerapan Unsur Penyalahgunaan dan Peredaran Merkuri dalam Tindak Pidana Lingkungan Hidup Berdasarkan Undang-undang Lingkungan Hidup dan Peraturan Daerah Provinsi Kalimantan Barat Nomor 4 Tahun 2007 (Studi Terhadap Putusan Majelis Hakim Pengadilan Negeri . Jurnal Nestor Magister Hukum Magister Hukum, 2(2). Retrieved from

https://media.neliti.com/media/publications/10669 -ID-penerapan-unsur-penyalahgunaan-danperedaran-merkuri-dalam-tindak-pidanalingkun.pdf

Perpres No. 21/2019 tentang Rencana Aksi Nasional Pengurangan dan Penghapusan Merkuri (2019).

Pinto, L. de C. M., Dórea, J. G., Bernardi, J. V. E., \& Gomes, L. F. (2019). Mapping the Evolution of Mercury (Hg) Research in the Amazon (1991-2017): A Scientometric Analysis. International Journal of Environmental Research and Public Health, 16(7), 1111. https://doi.org/10.3390/ijerph16071111

Sengupta, I. N. (1992). Bibliometrics, Informetrics, Scientometrics and Librametrics: An Overview. Libri, 42(2), 75-98. https://doi.org/https://doi.org/10.1515/libr.1992.4 2.2 .75

Silalahi, M., Santoso, A., \& Hidayat, D. (2019). A Scientometric Study on Biodiesel Development in
Indonesia. STI Policy and Management Journal, 4(1), 17-34. Retrieved from http://stipmjournal.org/index.php/stipm/article/vi ew/148/pdf

SK.340/Menlhk/Setjen/Kum.1/8/2018 tentang Komite Penelitian dan Pemantauan Merkuri di Indonesia (2018). Indonesia.

Sultan, S. N., Abidjulu, J., \& Koleangan, H. S. J. (2015). Analisis Kandungan Merkuri dan Sianida di Daerah Aliran Sungai Talawaan, Sulawesi Utara. Jurnal Ilmiah Sains, 15(1). Retrieved from https://ejournal.unsrat.ac.id/index.php/JIS/article/ view/8311/7870

UU Nomor 11/2017 tentang Pengesahan Minamata Convention On Mercury (Konvensi Minamata Mengenai Merkuri) (2017).

Wang, L., Xue, X., Zhang, Y., \& Luo, X. (2018). Exploring the Emerging Evolution Trends of Urban Resilience Research by Scientometric Analysis. International Journal of Environmental Research and Public Health, 15(10), 2181. https://doi.org/10.3390/ijerph15102181

White, E. R. (2019). Minimum Time Required to Detect Population Trends: The Need for Long-Term Monitoring Programs. BioScience, 69(1), 26-39. https://doi.org/10.1093/biosci/biy144 